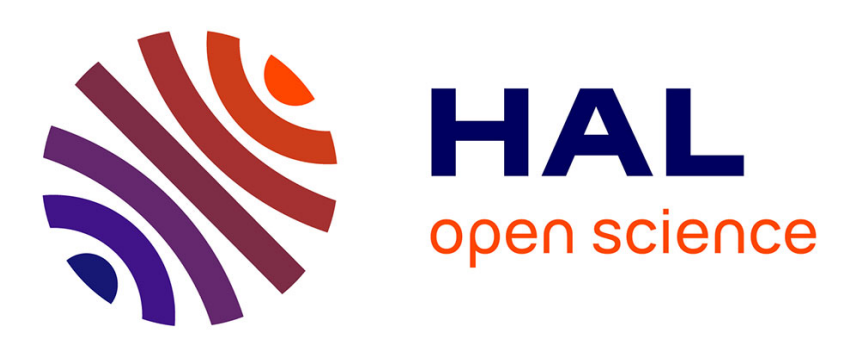

\title{
The predation impact of juvenile herring Clupea harengus and sprat Sprattus sprattus on estuarine zooplankton
}

\author{
Joachim Maes, Micky Tackx, Karline Soetaert
}

\section{To cite this version:}

Joachim Maes, Micky Tackx, Karline Soetaert. The predation impact of juvenile herring Clupea harengus and sprat Sprattus sprattus on estuarine zooplankton. Hydrobiologia, 2005, vol. $540\left(\mathrm{n}^{\circ} 1\right)$, pp. 225-235. 10.1007/s10750-004-7146-3 . hal-01514903

\section{HAL Id: hal-01514903 \\ https://hal.science/hal-01514903}

Submitted on 26 Apr 2017

HAL is a multi-disciplinary open access archive for the deposit and dissemination of scientific research documents, whether they are published or not. The documents may come from teaching and research institutions in France or abroad, or from public or private research centers.
L'archive ouverte pluridisciplinaire HAL, est destinée au dépôt et à la diffusion de documents scientifiques de niveau recherche, publiés ou non, émanant des établissements d'enseignement et de recherche français ou étrangers, des laboratoires publics ou privés. 


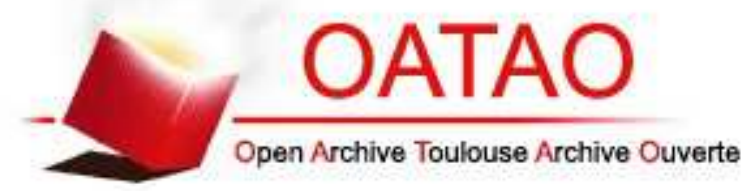

\section{Open Archive TOULOUSE Archive Ouverte (OATAO)}

OATAO is an open access repository that collects the work of Toulouse researchers and makes it freely available over the web where possible.

This is an author-deposited version published in : http://oatao.univ-toulouse.fr/ Eprints ID : 4439

To link to this article : DOI:10.1007/s10750-004-7146-3

URL : http://link.springer.com/article/10.1007/s10750-004-7146-3

To cite this version : Maes, Joachim and Tackx, Micky and Soetaert, Karline The predation impact of juvenile herring Clupea harengus and sprat Sprattus sprattus on estuarine zooplankton. (2005) Hydrobiologia, vol. 540 ( $\mathrm{n}^{\circ}$ 1). pp. 225-235. ISSN 0018-8158

Any correspondence concerning this service should be sent to the repository administrator: staff-oatao@ listes-diff.inp-toulouse.fr 


\title{
The predation impact of juvenile herring Clupea harengus and sprat Sprattus sprattus on estuarine zooplankton
}

\author{
Joachim Maes ${ }^{1, *}$, Micky Tackx ${ }^{2} \&$ Karline Soetaert ${ }^{3}$ \\ ${ }^{1}$ Katholieke Universiteit Leuven, Laboratory of Aquatic Ecology, Ch. De Bériotstraat 32, B-3000 Leuven \\ ${ }^{2}$ Université Paul Sabatier, Laboratoire d'Ecologie des Hydrosystèmes (LEH), bât 4R3 118 route de Narbonne, \\ 31062 Toulouse Cedex 4, France \\ ${ }^{3}$ Centre for Estuarine and Marine Ecology, Korringaweg 7, 4400 AC Yerseke, The Netherlands \\ (*Author for correspondence: Tel.: +32-16-323709, fax: +32-16-324575, E-mail: joachim.maes@bio.kuleuven.ac.be)
}

Key words: top-down control, predation, consumption, production, herring, sprat, calanoid copepods, estuary, Eurytemora affinis, Acartia tonsa

\begin{abstract}
The consumption of estuarine copepods by juvenile herring and sprat during estuarine residency was estimated using fish biomass data and daily rations calculated from two models of feeding in fish: a bioenergetic model and a gastric evacuation model. The bioenergetic model predicted daily rations that were, on average, three times higher than those estimated by a model based on field records of stomach contents. The biomass of herring and sprat in the estuary was negatively correlated with the daily ration suggesting that the clupeid fish populations were resource-limited. Copepod production decreased towards the winter and peaked in spring and summer. The relative importance of predation changed seasonally in function of the migration pattern of herring and sprat. In the spring and the summer, in situ production of copepod biomass was higher than the in situ consumption by fish. During the fall and the winter, consumption exceeded production. This suggests that top-down control exerted by marine pelagic fish may be an important force structuring estuarine copepod populations.
\end{abstract}

\section{Introduction}

Every winter, large numbers of young-of-the-year herring Clupea harengus L. and sprat Sprattus sprattus (L.) migrate to North Sea estuaries and become the dominant members of the estuarine fish assemblage, both by numbers and by biomass (Elliott et al., 1990; Power et al., 2000; Maes \& Ollevier, 2002). These migrations are characterised by the rapid movement of fish between the North Sea and the estuary and a rapid resulting increment in biomass, a relatively short residence time usually within the low-salinity zone of the river and high interannual variability in maximum abundance. Based on a dynamic model to simulate the optimal habitat use of juvenile herring, Maes et al. (2005) suggested that the temperature dif- ferential which exists between the sea and the estuary may be an important mechanism to initiate the migrations of young herring and sprat to estuaries. However, the relatively high estuarine zooplankton concentration during winter months in combination with the high estuarine turbidity is another potentially beneficial factor for fish that are able to switch from visual feeding to filter feeding such as clupeids. During their estuarine residency, young herring and sprat aggregate together in large fish schools and feed mainly on the large copepodite and adult stages of estuarine copepods (Maes \& Ollevier, 2002).

The high biomass of mesozooplankton in the brackish water part of temperate estuaries can be attributed to two species of calanoid copepods only: Eurytemora affinis (Poppe) and Acartia tonsa 
(Dana) (Soetaert \& Van Rijswijk, 1993; Sautour \& Castel, 1995). While the first species occurs throughout the year with a peak abundance in spring, the latter species is only important during late summer. Marine zooplankton that enter the estuary from the sea rapidly decline in numbers and are of no importance in the brackish water zone (Soetaert \& Herman, 1994).

The presence in large numbers of young-of-theyear herring and sprat in estuaries is thought to have concomitant effects on the trophic dynamics of estuaries (Henderson, 1989; Power et al., 2000). Nevertheless, the predation impact of pelagic marine fish on estuarine zooplankton is poorlydocumented (but see Thiel, 2001) or has yet to be quantified for most estuarine systems. This is due to a number of reasons. First, the quantitative assessment of the predation impact of pelagic fish upon zooplankton requires reliable biomass data. In estuaries, such information may be scarce since estuarine monitoring programs are often oriented towards benthic and demersal fish species, hereby using bottom trawls as sampling tool. The abundance of pelagic species is highly underestimated in such trawls. In addition, bottom trawling yields abundance or biomass estimates in catch per unit effort or, if the gear efficiency is known, numbers or biomass per sampled area. In contrast, zooplankton data are typically presented in numbers per sampled volume, so certain assumptions or extrapolations should be made before comparing the biomasses of the different consumer levels. In estuaries, pelagic fishes can be collected in stow nets or alternatively, via cooling water intakes to obtain quantitative samples in numbers per volume. Given that cooling water intakes are efficient sources to collect fish (Maes et al., 2001), this fishing method thus improves the quality of the estimated impact of pelagic fish on lower trophic levels.

A second difficulty in assessing the predation impact is the accurate measurement of the daily ration of fish. A daily ration or specific consumption rate is the amount of food that is consumed per day per gram body weight and varies with temperature, food type and food availability (Héroux \& Magnan, 1996). Direct estimation of the fish daily ration (as done in terrestrial animals) is difficult and in most cases, indirect estimates are obtained. One way of predicting the daily ration of fish is through the use of energetic models, which balance the consumed energy over metabolic processes and growth. Such models have successfully been applied to make consumer budgets of marine and freshwater fish populations (Kitchell \& Crowder, 1986; Rudstam, 1988; Arrhenius \& Hansson, 1993). Another approach to determine the daily ration in fish is to assess the change in stomach contents over time. This can be done in laboratory or field experiments but the daily ration of fish can also be derived from field observations. Different gastric evacuation models are available to fit in field data which result in an estimate of the daily ration (see Héroux \& Magnan (1996) for a review). However, in contrast to bioenergetic modelling, the latter approach is often time-consuming and requires considerable effort (Arrhenius \& Hansson, 1993).

In this paper, we analyse the dynamics of copepod consumption by herring and sprat during their estuarine residency in the Scheldt estuary (Belgium, The Netherlands). In lakes and coastal zones, planktivorous fish have been show to alter the species composition and size structure of zooplankton assemblages (Rudstam et al., 1992; Carpenter \& Kitchell, 1993; Mehner \& Thiel, 1999; Möllmann \& Köster, 2002), but their role in estuarine environments is less clear. A second aim was to compare and evaluate both models used to assess the fish daily ration to set a standard for future research analysing the interactions between estuarine fish and their prey.

\section{Material and methods}

\section{Field sampling and dissection of the fish}

Samples of zooplankton and fish were taken between August 1995 and September 1996 in the upper part of the Scheldt estuary nearby Doel (Belgium). A map of the study area and a complete description of the fishing method is given in Maes et al. (1998). The Scheldt is a macrotidal estuary with an average water depth of $11 \mathrm{~m}$. The upper part of the estuary where the sampling was conducted has an average salinity of $8 \mathrm{ppm}$. Oxygen concentrations at the time of sampling ranged between 2.6 and $10.6 \mathrm{mg}^{-1}$. The area is characterised by a high natural turbidity (Heip, 1988). 
Zooplankton was sampled $0.5 \mathrm{~m}$ below the surface with a 200-300 $\mu \mathrm{m}$ net. Abundance data (numbers $\mathrm{m}^{-3}$ ) were transformed to biomass data $\left(\mathrm{g} \mathrm{C} \mathrm{m}^{-3}\right.$ ) using individual copepod weights for subadult and adult copepods (Sautour \& Castel, 1995).

Herring and sprat were collected every month on the cooling-water filter screens of the nuclear power plant Doel. Numbers per sample were transformed to numbers $10^{-3} \mathrm{~m}^{-3}$ cooling-water sampled (density). The biomass $\left(\mathrm{g} \mathrm{C} \mathrm{m}^{-3}\right)$ was calculated as the product between the fish density and the average fish carbon weight ( $\mathrm{g} C$ ), estimated using length-weight regressions:

$$
\begin{aligned}
\log w_{\mathrm{H}}=- & 12.13+2.69 \log L_{\mathrm{H}} \\
& (\text { Maes \& Ollevier, 2000), } \\
\log w_{\mathrm{S}}=- & 15.16+3.36 \log L_{\mathrm{S}}
\end{aligned}
$$

(Hostens \& Hamerlynck, 1993),

where $w_{\mathrm{H}}$ and $w_{\mathrm{S}}$ denote individual herring and sprat biomass $(\mathrm{g} \mathrm{C})$, respectively and $L_{\mathrm{H}}$ and $L_{\mathrm{S}}$ are total herring and sprat length $(\mathrm{mm})$, respectively.

Each month, 20 individuals per fish species were randomly collected approximately every $3 \mathrm{~h}$ over a $24 \mathrm{~h}$-interval. Stomach contents were removed, pooled, dried at $70{ }^{\circ} \mathrm{C}$ to constant weight and weighed to the nearest $0.01 \mathrm{mg}$. The average stomach weight was calculated by dividing the pooled weight by 20 .

\section{Clupeid daily ration and consumption}

Two models of feeding in fish were used to estimate the daily ration of herring and sprat during their estuarine residency: a bioenergetic model and a stomach content evacuation model using field data.

Rudstam (1988) developed a bioenergetic model for herring, structured after a model for alewife by Stewart \& Binowski (1986). We used this model to simulate the daily consumption of herring and sprat during estuarine residency. Bioenergetic models allocate daily consumed energy $C$ over metabolic processes such as respiration $R$ and specific dynamic action $S$, waste losses due to egestion $F$ and excretion $E$ and growth $g$ such that

$$
g=C-[R+S+F+E] .
$$

For the purpose of this paper, we present only the mathematical formulation of consumption. We further assume that the bioenergetics of sprat has the same characteristics as equally sized herring (Arrhenius \& Hansson, 1993). Submodels for respiration and waste losses can be found in Rudstam (1988), Arrhenius (1998) and Maes et al. (2005). The daily ration or specific consumption rate $C$ $\left(\mathrm{g} \mathrm{g}^{-1} \mathrm{~d}^{-1}\right)$ of herring and sprat is calculated using Equation (4).

$$
C=C_{\max } \times f(T) \times P \text { and } C_{\max }=a w^{-b},
$$

where $w$ (g wet weight) is fish body weight, $a$ is the maximum specific consumption $\left(0.642 \mathrm{~g} \mathrm{~g}^{-1}\right.$ day $\left.^{-1}\right), b$ is the slope of maximum consumption (0.256). The temperature-dependence of maximum consumption $f(T)$ was defined by an algorithm (Thornton \& Lessem, 1978). The parameters for the temperature algorithm can be found in Rudstam (1988) and Hanson et al. (1997). $P$ is a fraction of maximum daily consumption, and is found by fitting Equation (3) to growth data. We assumed that the large majority of age- 0 herring caught in the estuary originates from the Downs herring stock in the southern part of the North Sea. Hence, simulations of growth started 1 January 1994 at a weight of $25 \mathrm{mg}$ (Heath et al., 1997). We forced the growth curve through a weight of $5.7 \mathrm{~g}$, corresponding to a length at age 1 (1 January 1995) of $9 \mathrm{~cm}$. This procedure yielded a value of 0.228 for $p$. As a result, the realised consumption is $22.8 \%$ of the maximum consumption after modification by the temperature algorithm. This value falls within reported values for other clupeoids (Stewart and Binowski, 1986; Rudstam, 1988; Limburg, 1996) giving confidence in the growth model used.

The daily ration of fish can also be determined using the decline in stomach contents during a day. The evacuation of food can be estimated under laboratory conditions as the slope of the relationship between digestive track contents and time while fish are not fed or, under field situations, as the steepest slope of the daily survey of the stomach contents (Boisclair \& Marchand, 1993). Since young herring and sprat are extremely sensitive to laboratory handling and contact with high associated mortality, we have used the latter method to estimate the evacuation rate. Following Möllmann \& Köster (1999), the daily ration of herring and 
sprat was estimated using an exponential form of the gastric evacuation model proposed by Jones (1974). Ambient water temperature $T\left({ }^{\circ} \mathrm{C}\right)$ was incorporated as a variable.

$$
S_{t}=S_{\mathrm{o}} \times \exp [-r \times \exp (c T) \times t]
$$

where $S_{t}$ is stomach content (g dry weight) at time $t ; S_{\mathrm{o}}$ is the stomach content (g dry weight) at time $0 ; r$ is the evacuation rate $\left(\mathrm{h}^{-1}\right) ; c$ is a temperature coefficient. Carbon weight of the ingested zooplankton was assumed to be $50 \%$ of the dry weight (Escaravage \& Soetaert, 1995). The model parameters $r$ and $c$ were estimated by fitting Equation 5 through the set of 14 field observations for $S_{t}$ and $S_{\mathrm{o}}$ assuming that gastric evacuation can be estimated from a decline in stomach contents observed during a time interval $t$. For each month, the evacuation rate is thus estimated using the maximum observed daily stomach content as a value for $S_{\mathrm{o}}$ and the subsequent minimum observed stomach content as a value for $S_{t}$. For herring, this procedure yielded 0.086 for $r$ and 0.044 for $c$ (Non-linear regression, $N=14$; $\left.R^{2}=0.91\right)$. For sprat, $r$ and $c$ were estimated 0.086 and 0.037 , respectively (Non linear regression, $\left.N=14 ; \quad R^{2}=0.90\right)$. According to Pennington (1985), the daily ratio $C$ can be estimated as

$$
C=[r \times \exp (c T)] \times S \times t \times w^{-1},
$$

where $t$ is the duration of the feeding period, $S$ is the average stomach content and $w$ is the average weight of the fish $(\mathrm{g} \mathrm{C})$. The feeding period $t$ was set at $24 \mathrm{~h}$.

The daily consumption or food intake of zooplankton biomass by herring and sprat in $\mathrm{g} \mathrm{C}$ zooplankton $\mathrm{m}^{-3} \mathrm{~d}^{-1}$ was finally assessed by multiplying the biomass of herring and sprat $\left(\mathrm{g} \mathrm{C} \mathrm{m}^{-3}\right)$ with the daily ration $\left(\mathrm{d}^{-1}\right)$ as calculated according the two feeding models.

\section{Copepod daily production}

The production of copepod biomass $\left(\mathrm{g} \mathrm{C} \mathrm{m}^{-3} \mathrm{~d}^{-1}\right)$ was assessed by multiplying the copepod biomass as recorded in the field $\left(\mathrm{g} \mathrm{C} \mathrm{m}^{-3}\right)$ with a weightspecific growth rate $g\left(\mathrm{~d}^{-1}\right)$ in function of temperature (Escaravage \& Soetaert, 1995; Escaravage, personal communication). For Eurytemora affinis, a quadratic model adequately described the weight-specific growth rate in function of temperature $T$. For Acartia tonsa, a linear model in function of temperature $T$ was applied.

\section{Eurytemora affinis}

$$
\begin{aligned}
& g=0.0008 T^{2} \quad \text { for } T<13.8^{\circ} C, \\
& g=-0.0028 T^{2}+0.0944 T-0.617 \text { for } T>13.8^{\circ} C .
\end{aligned}
$$

Acartia tonsa

$$
g=0.043 T-0.28
$$

\section{Results}

\section{Annual changes in copepod and clupeid biomass}

The biomass of calanoid copepods reached maximum values in April and September, due to distinct abundance peaks of Eurytemora affinis and Acartia tonsa, respectively (Fig. 1). Stomach contents contained mainly larger copepodite and adult copepod stages but sometimes mysids also occurred in the diet of herring. Since naupliar stages were not found in the stomachs of the fish, we presented only results for the larger copepodite stages (IV, V) and the adult stages of Acartia tonsa and Eurytemora affinis in this paper. Herring and sprat peaked in biomass in November (Fig. 2). Their abundance pattern was mainly determined by migrations of 0-group individuals between the North Sea and the Scheldt estuary with typical annual maxima between November and February. During most part of the year, the cumulated biomass of juvenile herring and sprat in the estuary exceeded the biomass of the subadult and adult stages of calanoid copepods. In spring, when most herring and sprat have left the estuary to join adult North Sea stocks, the copepod biomass became larger than the clupeid biomass. There was no correlation between the biomass of herring and sprat on the one hand and the biomass of copepods on the other hand (Spearman rank correlation test; $N=13 ; r=-0.25 ; p=0.40$ ).

\section{Clupeid daily ration}

There was considerable variation in the daily ration of both herring and sprat depending on the feeding 


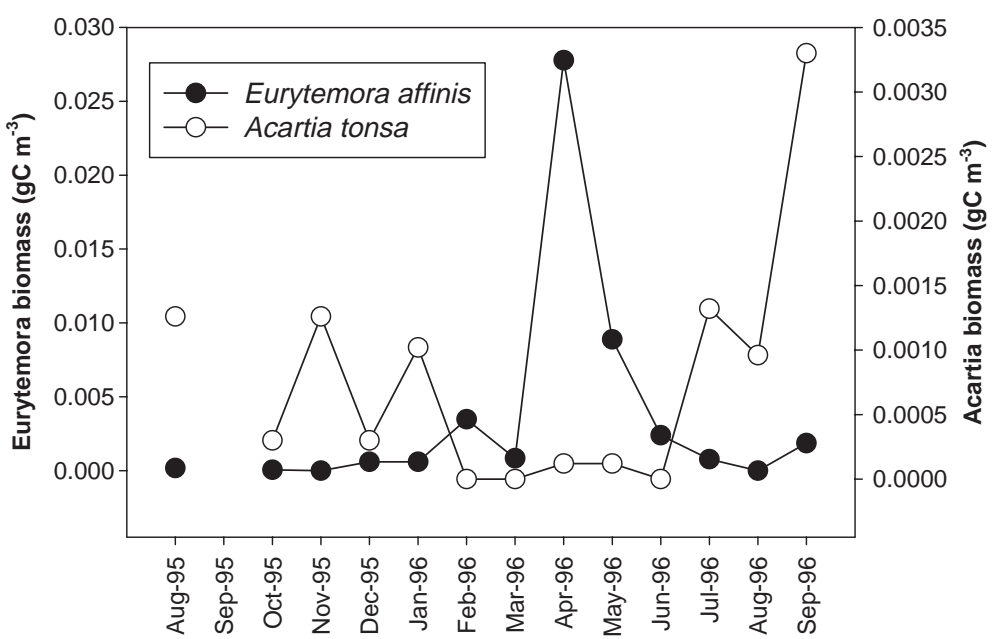

Figure 1. Monthly changes in the biomass of two dominant copepod species in the upper part of the Scheldt estuary at Doel (Belgium) between August 1995 and September 1996. Data for September 1995 is lacking. Different scales are used.

model used (Table 1). The bioenergetic model predicted higher specific consumption rates than the model based on the evacuation of food. Using bioenergetics, the daily ration of herring ranged between 0.6 and $18.6 \%$ of its body weight per day. The modelled ration of herring peaked at a temperature of $17{ }^{\circ} \mathrm{C}$ resulting in two annual maxima before and after the summer (Table 1). Based on a stomach contents evacuation model, herring consumed each day between 0.09 and $6.7 \%$ of its body weight. Also for sprat, the two feeding models yielded different rations (Table 1). The daily ration predicted by the bioenergetic model varied from 0.7 to $15.6 \%$ of the bodyweight consumed per day while the evacuation model resulted in rations of between 0 and $3.8 \%$ bodyweight per day.

The biomass of herring was negatively related to the daily ration based on field records of stomach contents (Spearman rank correlation test: $N=14 ; r=-0.65, p<0.05)$. A similar result was found for sprat (Spearman rank correlation test: $N=14 ; r=-0.70 ; p<0.05)$.

\section{In situ copepod production and clupeid food demand}

Estuarine fish biomass and fish daily ration were multiplied to calculate the consumed copepod biomass per day (Fig. 2). Although consumption was mainly determined by the seasonal changes in fish biomass, there still remained a difference of one order of magnitude between the two feeding mod- els that were used to assess the daily ration. When the food intake was integrated over 1 year, sprat

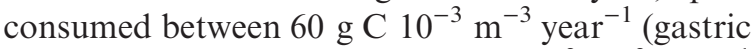

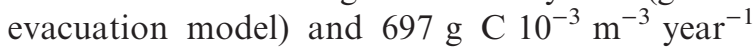
(bioenergetic model). The annual consumption of

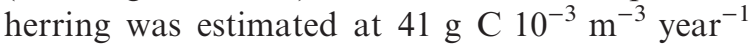
using the evacuation model and $399 \mathrm{~g}$ C $10^{-3} \mathrm{~m}^{-3}$ year ${ }^{-1}$ using the bioenergetic model.

In Figure 3, the production of copepods was compared with the consumption of copepods by clupeid fish. Copepod production decreased towards the winter and peaked in spring and summer. During the fall and the winter, fish consumption exceeded copepod production. This suggested that there was a net loss of copepod biomass due to fish predation. In spring and summer, production of copepod biomass was higher than the consumption.

\section{Discussion}

This study is the first to estimate the predation impact of fish on calanoid copepods in the Scheldt estuary. Our calculations show that herring and sprat exert a strong predation pressure on the larger copepodites and copepods. The relative importance of predation changed seasonally in relation to the migration pattern of yearling herring and sprat with peak predation occurring in autumn. Our results indicate that in this season, fish predation is possibly an important 
cause for the decline of the biomass of larger copepodites and adult copepods suggesting a top-down effect.

Which feeding model should be used to calculate the daily ration of herring and sprat

The extent of food consumption by clupeids largely depended on the feeding model used to assess the fish daily ration with the bioenergetic model predicting the highest daily rations. Models using field observations of stomach contents and a resulting gastric evacuation rate to calculate the daily ration implicitly take into account the availability of food resources as well as any other biotic interactions between competitors. In contrast, bioenergetic models are based on the individual needs of fish to realise a certain weight at
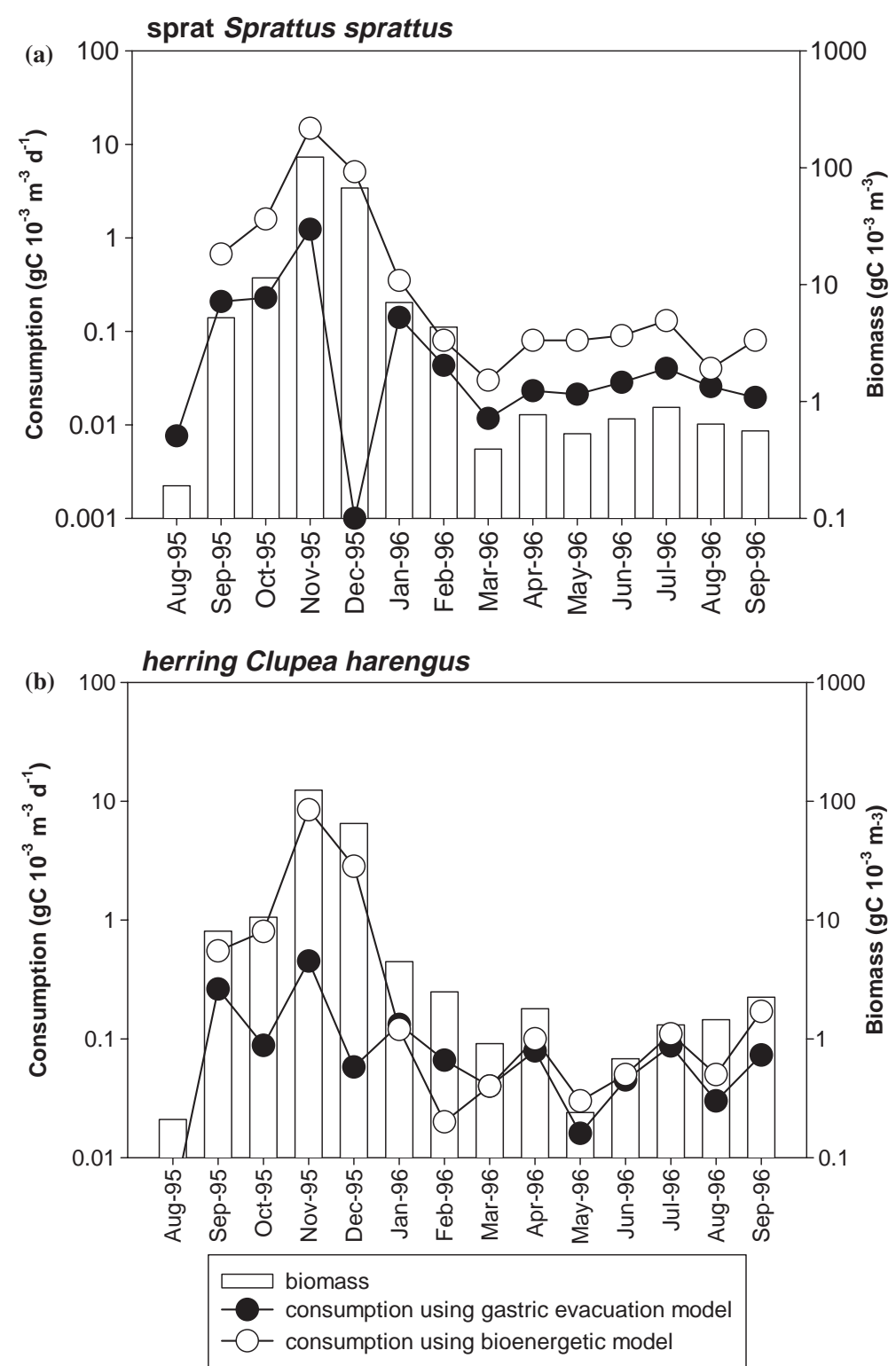

Figure 2. Biomass and daily food consumption of sprat (a) and herring (b) during estuarine residency between August 1995 and September 1996 assessed using two different models of feeding in fish. 
Table 1. Monthly changes in the daily ration of herring and sprat in the Scheldt estuary captured at the cooling water intake of the power plant Doel (Belgium) between August 1995 and September 1996

\begin{tabular}{|c|c|c|c|c|c|c|}
\hline & Temperature & Average size & $\begin{array}{l}\text { Average stomach } \\
\text { contents }\end{array}$ & $\begin{array}{l}\text { Evacuation } \\
\text { rate }\end{array}$ & $\begin{array}{l}\text { Daily ration } \\
\text { (GEM) }\end{array}$ & $\begin{array}{l}\text { Daily ration } \\
(\mathrm{BEM})\end{array}$ \\
\hline & ${ }^{\circ} \mathrm{C}$ & $\mathrm{g} \mathrm{C}$ & $\mathrm{mg} \mathrm{C}$ & $\mathrm{h}^{-1}$ & $\% \mathrm{BW}$ & $\% \mathrm{BW}$ \\
\hline \multicolumn{7}{|l|}{ Herring } \\
\hline Aug 95 & 23.5 & 0.29 & 1.04 & 0.24 & 2.0 & 0.6 \\
\hline Sep 95 & 18.8 & 0.59 & 4.10 & 0.20 & 3.2 & 10.4 \\
\hline Oct 95 & 17.2 & 0.74 & 1.41 & 0.18 & 0.8 & 11.6 \\
\hline Nov 95 & 11.9 & 0.76 & 0.80 & 0.14 & 0.4 & 10.5 \\
\hline Dec 95 & 6.9 & 0.67 & 0.21 & 0.12 & 0.1 & 6.7 \\
\hline Jan 96 & 5.0 & 0.74 & 8.60 & 0.11 & 3.0 & 4.2 \\
\hline Feb 96 & 1.9 & 0.75 & 8.85 & 0.09 & 2.6 & 1.5 \\
\hline Mar 96 & 6.6 & 0.99 & 16.02 & 0.11 & 4.4 & 6.1 \\
\hline Apr 96 & 9.2 & 1.02 & 14.72 & 0.13 & 4.4 & 8.3 \\
\hline May 96 & 14.4 & 0.18 & 3.10 & 0.16 & 6.7 & 18.6 \\
\hline Jun 96 & 19.5 & 0.20 & 2.76 & 0.20 & 6.7 & 12.1 \\
\hline Jul 96 & 18.0 & 0.22 & 3.24 & 0.19 & 6.7 & 13.0 \\
\hline Aug 96 & 21.0 & 0.31 & 1.22 & 0.22 & 2.0 & 5.5 \\
\hline Sep 96 & 15.5 & 0.55 & 4.40 & 0.17 & 3.2 & 11.7 \\
\hline \multicolumn{7}{|l|}{ Sprat } \\
\hline Aug 95 & 23.5 & 0.20 & 1.52 & 0.21 & 3.8 & 0.8 \\
\hline Sep 95 & 18.8 & 0.29 & 2.61 & 0.17 & 3.8 & 12.8 \\
\hline Oct 95 & 17.2 & 0.31 & 1.58 & 0.16 & 2.0 & 13.9 \\
\hline Nov 95 & 11.9 & 0.46 & 0.77 & 0.13 & 0.5 & 12.0 \\
\hline Dec 95 & 6.9 & 0.48 & 0.00 & 0.11 & 0.0 & 7.6 \\
\hline Jan 96 & 5.0 & 0.49 & 3.69 & 0.10 & 1.9 & 4.9 \\
\hline Feb 96 & 1.9 & 0.48 & 2.60 & 0.09 & 1.2 & 1.8 \\
\hline Mar 96 & 6.6 & 0.44 & 5.30 & 0.11 & 3.2 & 7.4 \\
\hline Apr 96 & 9.2 & 0.49 & 5.36 & 0.12 & 3.2 & 10.5 \\
\hline May 96 & 14.4 & 0.14 & 1.45 & 0.15 & 3.8 & 15.6 \\
\hline Jun 96 & 19.5 & 0.18 & 1.63 & 0.18 & 3.8 & 12.4 \\
\hline Jul 96 & 18.0 & 0.20 & 1.85 & 0.17 & 3.8 & 15.1 \\
\hline Aug 96 & 21.0 & 0.20 & 1.70 & 0.19 & 3.8 & 6.6 \\
\hline Sep 96 & 15.5 & 0.29 & 2.95 & 0.15 & 3.8 & 14.3 \\
\hline
\end{tabular}

Daily rations (\% body weight, \% $\mathrm{BW}$ ) were calculated using two models of feeding in fish: a gastric evacuation model (GEM) and a bioenergetic model (BEM). The daily ration based on gastric evacuation is derived from field data and calculated using average stomach contents (carbon weight, $\mathrm{mg} \mathrm{C}$ ) and the gastric evacuation rate (Equation (6)). The gastric evacuation rate is calculated using temperature and stomach contents data (Equation (5)). The daily ration based on bioenergetics is assessed using average fish size (carbon weight, $\mathrm{gC}$ ) and temperature data (Equation (4)).

age, regardless of the ambient resource availability. Thus, in case of limited resources, bioenergetic models easily overestimate consumption. Low copepod abundance for instance in October and December 1995, in combination with high clupeid abundance likely resulted in minimum daily rations according to the gastric evacuation model and higher rations according to the individuallybased bioenergetic approach.

There is second reason to explain the high daily rations predicted by the bioenergetic model i.e. the extrapolation of allometric functions of respira- 


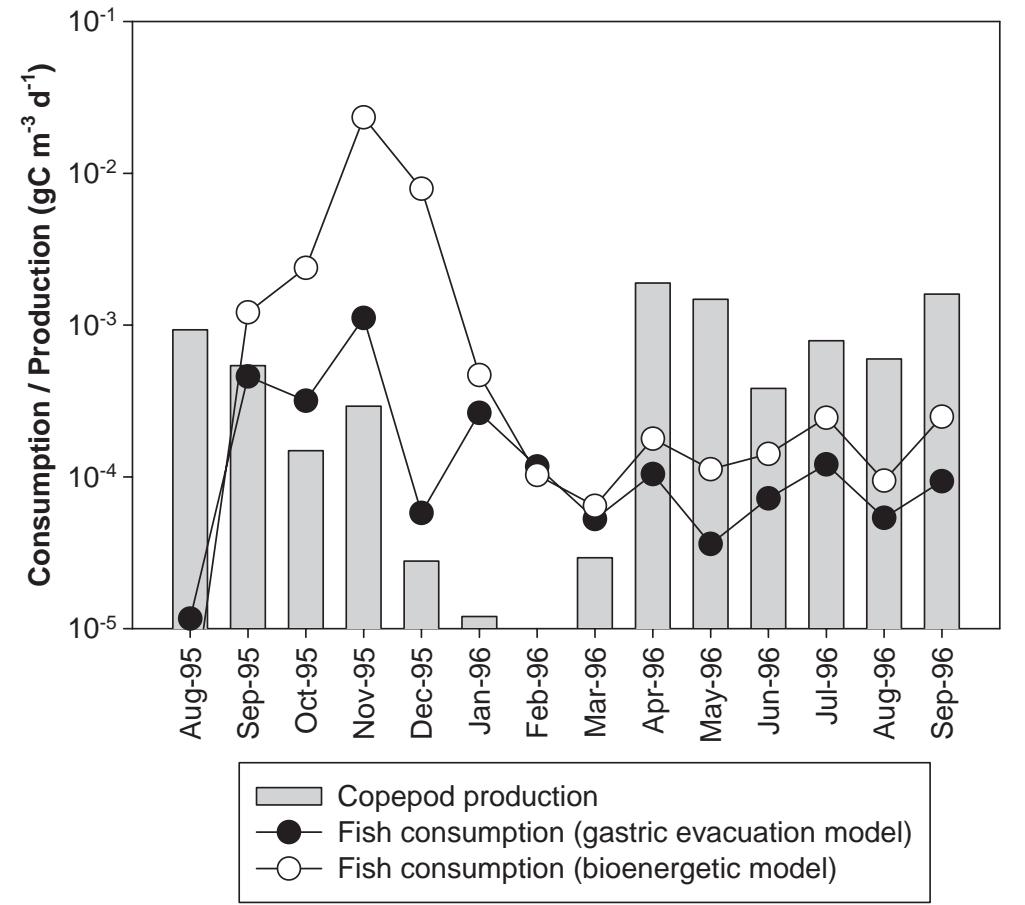

Figure 3. Copepod production (copepodite and adult stages) vs. fish consumption. Copepod production was calculated using copepod biomass and temperature dependent growth rates. Fish consumption was assessed using a gastric evacuation model and a bioenergetic model.

tion and consumption from adult fish to juveniles. Post (1990) reported considerable differences between the actual food consumption of young of the year Perca flavescens and consumption estimated from a bioenergetic model based on data from older fish. Arrhenius \& Hansson (1994a,b) compared the in situ food consumption of young of the year Baltic herring with estimations from the same bioenergetic model as used in this study. They found that the bioenergetic model overestimated the daily ration of 0 -group herring by a factor of 2. The difference between the field model and the bioenergetic model is related to differences in the standard metabolic rate between larvae or juveniles on the one hand and adult fish on the other hand. In bioenergetic models, the standard metabolic rate is expressed as an allometric function of body size. For adult fish, the exponent is assumed constant at about 0.8 (Clarke \& Johnston, 1999), but the exponent may be different for young fish (Hanson et al., 1997; Klumb et al., 2003). Arrhenius (1998) suggested to use a revised model for young Baltic herring with alternative formulations for swimming speed and variable daily feeding periods. We have not followed this approach for two reasons. Firstly, the bioenenergetic model for herring developed by Rudstam (1988) was written using physiological parameters derived from a laboratory study by De Silva \& Balbontin (1974) for young Atlantic herring. Secondly, our field observations suggest that herring and sprat also feed during night. In an earlier paper (Maes \& Ollevier, 2002), we have hypothesised that this behaviour relates to the high turbidity of estuarine waters encouraging herring and sprat to filter-feed rather than to feed visually. Filter-feeding schools of herring and sprat are not constrained by light and under such conditions, feeding becomes a type I response to zooplankton concentration.

While the bioenergetic modelling approach overestimates the daily ration, it can be expected that the feeding model using field observations is underestimating the actual consumption. The evacuation rate $R$ corresponds to the slope of the relation between food content and time for fish 
evacuating food during a complete evacuation cycle in field or laboratory experiments (Héroux \& Magnan, 1996). In field studies like this one, the evacuation rate is derived from an observed decline in stomach contents. In case of incomplete food evacuation, this procedure yields an underestimated value for $R$ resulting, in turn, in an underestimation of the daily ration. Consequently, we interpret our results for the daily rations based on the gastric evacuation model and the bioenergetic model as minimum and maximum values for consumption, respectively.

\section{Evidence for top-down control of estuarine copepods?}

The difference between the two models of feeding in fish did not affect our conclusion that clupeid predation resulted in the net loss of copepod biomass during the second half of the year. Further, we found a negative correlation between the daily ration calculated using stomach content data and the herring and sprat population biomass. These observations suggest that the copepodite and adult stages of the estuarine copepods Eurytemora affinis and Acartia tonsa are top-down controlled rather than bottom-up limited by food resources and that clupeid fish populations visiting the estuary are resource-limited. In the Scheldt estuary, copepods feed selectively on phytoplankton, even in the detritus dominated maximum turbidity zone (Tackx et al., 2003). Escaravage \& Soetaert (1995) showed, however, that the in situ produced phytoplankton is only sufficient to meet the nutritional demands of the two copepod species during a limited period of the year (May and June) when the algal biomass is reaching maximum values. During the rest of the year, the consumption of copepods exceeds the phytoplankton primary production in the brackish water part of the estuary suggesting food limitation. However, copepods are able to feed on detritus which is in the Scheldt estuary not in short supply. But at present, it is unclear to which degree copepods add detritus to their diet in case of shortage of phytoplankton.

Cascading effects are an accepted concept in freshwater ecology (Carpenter \& Kitchell, 1993) and there is growing evidence that top-down control also modulates to some extent the zoo- plankton dynamics in the North Sea (Reid et al., 2000 and references therein), the Baltic Sea (Rudstam et al., 1994) and nutrient upwelling areas (Cury et al., 2000). Whereas our results clearly show that the decline in copepods at the end of the summer and further during the fall can be attributed to fish predation, the observed pattern in fish consumption could not explain the typical Eurytemora/Acartia species succession that is characteristic for the brackish zone of many European estuaries just before the summer. The decline in the abundance of Eurytemora affinis as reported in Escaravage \& Soetaert (1995) coincides with the annual ingress of large numbers of herring and sprat larvae in the cooling water intake at Doel. Although larval abundance could not be quantified on the filter screens due to the mesh size of the filters $(4 \mathrm{~mm})$, we hypothesize that the consumption of copepod nauplii by larvae contributes to the typical population collapse. Other studies confirm that fish larvae consume a significant part of the zooplankton production. In the Baltic Sea, larval herring and sprat accounted for $15 \%$ of the total zooplankton consumption by the clupeid fish populations in the Baltic sea (Arrhenius \& Hansson, 1993). Thiel (1996) showed that in a shallow brackish bay of the southern Baltic Sea, predation by $0+, 1+$ and small adults of zooplanktivorous fish led to the total collapse of the copepod and cladoceran populations in May and June. Consumption by larvae and $0+$ juveniles accounted for $85 \%$ of the zooplankton consumption.

\section{Interannual variability of copepod consumption}

Long term monitoring of the estuarine fish assemblage using samples taken at the filter screens of the Doel power station (1991-2000) suggests that the seasonal migration patterns of herring and sprat are predictable. Therefore, we expect that the autumn and winter abundance of estuarine copepods is controlled every year by clupeid fish populations. The extent of these cascading effects is, however, highly variable. Already Rudstam et al. (1992) pointed out that year to year variation in absolute levels of planktivory in the Baltic Sea may be substantial due to variable year class strength of planktivores. In the cooling water catches at Doel, the peak abundance of 
herring and sprat varied by a factor 15 for the years 1994 and 1996. It is thus possible that, in some years, clupeid migrations lead to the rapid decline of the copepod numbers in the estuary while in other years, top-down control may be weak. So far, the impact of yearly changing quantities of juvenile fish on the long-term stability of estuarine copepod populations has not been investigated. Besides the regular monitoring of both fish and plankton, such research would clearly benefit from a revised bioenergetic model for yearling herring and sprat to make better predictions of the fish daily ration.

\section{Acknowledgements}

Joachim Maes is a postdoctoral fellow and the Fund for Scientific Research - Flanders (Belgium). This study was supported by the projects G.0104.99 and W 10/5 - CVW.D 13.816 of the Fund for Scientific Research - Flanders (Belgium) and the OMES project financed by the Flemish government. Joachim Maes is grateful to Lars Rudstam and Don Stewart for their useful comments on the bioenergetics of herring.

\section{References}

Arrhenius, F., 1998. Variable length of daily feeding period in bioenergetics modelling: a test with 0 -group Baltic herring. Journal of Fish Biology 52: 855-860.

Arrhenius, F. \& S. Hansson, 1993. Food consumption of larval, young and adult herring and sprat in the Baltic Sea. Marine Ecology Progress Series 96: 125-137.

Arrhenius, F. \& S. Hansson, 1994a. In situ food consumption by young-of-the-year Baltic Sea herring Clupea harengus: a test of predictions from a bioenergetics model. Marine Ecology Progress Series 110: 145-149.

Arrhenius, F. \& S. Hansson, 1994b. Erratum. Marine Ecology Progress Series 114: 314.

Boisclair, D. \& F. Marchand, 1993. The guts to estimate fish daily ration. Canadian Journal of Fisheries and Aquatic Sciences 50: 1969-1975.

Carpenter S. R. \& J. F. Kitchell, 1993. The Trophic Cascade in Lakes. Cambridge University Press, New York, 385 pp.

Clarke, A. \& N. Johnston, 1999. Scaling of metabolic rate with body mass and temperature in teleost fish. Journal of Animal Ecology 68: 893-905.

Cury, P., A. Bakun, R. J. M. Crawford, A. Jarre, R. A. Quinones, L. J. Shannon \& H. M. Verheye, 2000. Small pelagics in upwelling systems: patterns of interaction and structural changes in "wasp-waist" ecosystems. ICES Journal of Marine Science 57: 603-618.
De Silva, S. S. \& F. Balbontin, 1974, Laboratory studies on food intake, growth and food conversion of young herring, Clupea harengus (L.). Journal of Fish Biology 6: 645-648.

Elliott, M., M. G. O'Reilly \& C. J. L. Taylor, 1990, The Forth estuary: a nursery and overwintering area for North Sea fishes. Hydrobiologia 195: 89-103.

Escaravage, V. \& K. Soetaert, 1995, Secondary production of the brackish copepod community and their contribution to the carbon fluxes in the Westerschelde estuary (The Netherlands). Hydrobiologia 311: 103-114.

Hanson, P. C., T. B. Johnson, D. Z. Schindler \& J. F. Kitchell, 1997. Fish Bioenergetics 3.0 for Windows. University of Wisconsin. Madison Center for Limnology and Sea Grant Institute.

Heath, M., B. Scott \& A. D. Bryant, 1997, Modelling the growth of herring from four different stocks in the North Sea. Journal of Sea Research 38: 413-436.

Heip, C., 1988. Biota and abiotic environment in the Westerschelde estuary. Hydrobiological Bulletin 22: 31-34.

Henderson, P. A., 1989. On the structure of the inshore fish community of England and Wales. Journal of the Marine Biological Association of the United Kingdom 69: 145-163.

Héroux, D. \& P. Magnan, 1996. In situ determination of food daily ration in fish: review and field evaluation. Environmental Biology of Fishes 46: 61-74.

Hostens, K., \& O. Hamerlynck, 1993. Rol van de mobiele epifauna in de Oosterschelde. Rapporten en verslagen 1993 03. Centre for estuarine and marine ecology, Yerseke, The Netherlands.

Jones, R., 1974. The rate of elimination of food from stomachs of haddock Melanogrammus aeglefinus, cod Gadus morhua and whiting Merlangius merlangus. Journal du Conseil International de l'Exploration de la Mer 35: 225-243.

Kitchell, J. F. \& L. D. Crowder, 1986. Predator-prey interactions in Lake Michigan: model predictions and recent dynamics. Environmental Biology of Fishes 16: 205-211.

Klumb, R. A., L. G. Rudstam \& E. L. Mills, 2003, Comparison of alewife young of the year and adult respiration and swimming speed bioenergetics model parameters: implications of extrapolation. Transactions of the American Fisheries Society 132: 1089-1103.

Limburg, K. E., 1996. Modelling the ecological constraints on growth and movement of juvenile American shad (Alosa sapidissima) in the Hudson river estuary. Estuaries 19: 794-813.

Maes, J., K. E. Limburg, A. Van De Putte \& F. Ollevier, 2005. A spatially explicit individual-based model to assess the role of estuarine nurseries in the early life history of North Sea herring, Clupea harengus. Fisheries Oceanography 14: 17-31.

Maes, J., J. Pas, A. Taillieu, P. A. Van Damme \& F. Ollevier, 2001. Sampling fish and crustaceans at an estuarine power plant cooling-water intake: a comparison with stow net fishery. Archive of Fishery and Marine Research 49: 27-36.

Maes, J. \& F. Ollevier, 2000. Biomass transport to and from an upper estuarine area by migration of juvenile Atlantic herring Clupea harengus L. Canadian Journal of Fisheries and Aquatic Sciences 57: 1404-1409.

Maes, J., A. Taillieu, P. A. Van Damme, K. Cottenie \& F. Ollevier, 1998, Seasonal Patterns in the Fish and Crustacean Community of a Turbid Temperate Estuary (Zeeschelde Estuary, Belgium). Estuarine, Coastal and Shelf Science 47: 143-151 
Mehner, T. \& R. Thiel, 1999. A review of predation impact by $0+$ fish on zooplankton in fresh and brackish waters of the temperate northern hemisphere. Environmental Biology of Fishes 56: 169-181.

Möllmann, C. \& F. W. Köster, 1999. Food consumption by clupeids in the Central Baltic: evidence for top-down control? ICES Journal of Marine Science 56 (suppl.): 100-113.

Möllmann, C. \& F. W. Köster, 2002. Population dynamics of calanoid copepods and the implications of their predation by clupeid fish in the Central Baltic Sea. Journal of Plankton Research 24: 959-977.

Pennington, M., 1985. Estimating the average food consumption by fish in the field from stomach contents data. Dana 5: 81-86.

Post, J. R., 1990. Metabolic allometry of larval and juvenile yellow perch (Perca flavescens): in situ estimates and bioenergetics models. Canadian Journal of Fisheries and Aquatic Sciences 47: 554-560.

Power, M., M. J. Attrill \& R. M. Thomas, 2000. Temporal abundance patterns and growth of juvenile herring and sprat from the Thames estuary 1977-1992. Journal of Fish Biology 56: 1408-1426.

Reid, P. C., E. J. V. Battle, S. D. Batten \& K. M. Brander, 2000. Impact of fisheries on plankton structure. ICES Journal of Marine Science 57: 495-502.

Rudstam, L. G., 1988. Exploring the dynamics of herring consumption in the Baltic: applications of an energetic model of fish growth. Kieler Meeresforsuchungen Sonderheft 6: 312-322.

Rudstam, L. G., G. Aneer \& M. Hildén, 1994. Top-down control in the pelagic Baltic ecosystem. Dana 10: 105-129.
Rudstam, L. G., S. Hansson, S. Johansson \& U. Larsson, 1992. Dynamics of planktivory in a coastal area of the northern Baltic Sea. Marine Ecology Progress Series 80: 159-173.

Sautour, B. \& J. Castel, 1995. Comparative spring distribution of zooplankton in three macrotidal European estuaries. Hydrobiologia 311: 139-151.

Soetaert, K. \& P. M. J. Herman, 1994. One foot in the grave: zooplankton drift into the Westerschelde estuary. Marine Ecology Progress Series 105: 19-29.

Soetaert, K. \& P. Van Rijswijk, 1993. Spatial and temporal patterns of the zooplankton in the Westerschelde estuary. Marine Ecology Progress Series 97: 47-59.

Stewart, D. J. \& F. B. Binowski, 1986, Dynamics of consumption and food conversion by alewives: a energeticmodelling synthesis. Transactions of the American Fisheries Society 115: 643-661.

Tackx, M. L. M., P. M. J. Herman, S. Gasparini, X. Irigoien, R. Billiones \& M. H. Daro, 2003, Selective feeding of Eurytemora affinis (Copepoda, Calanoida) in temperature estuaries: model and field observations. Estuarine Coastal and Shelf Science 56: 305-311.

Thiel, R., 1996. The impact of fish predation on the zooplankton community in a southern Baltic bay. Limnologica (Berlin) 26: 123-137.

Thiel, R., 2001. Spatial gradients of food consumption and production of juvenile fish in the lower River Elbe. Archiv fur Hydrobiologie Supplement 135: 441-462.

Thornton, K. W. \& A. S. Lessem, 1978. Temperature algorithm for modifying biological rates. Transactions of the American Fisheries Society 107: 284-287. 